\title{
The COVID-19 Pandemic: Perspectives for Reimaging and Reimagining Archaeological Practice
}

\author{
Akinwumi Ogundiran
}

Published online: 2 September 2020

C) Springer Science+Business Media, LLC, part of Springer Nature 2020

Like other branches of historical studies, archaeology is the study of the past in the present. It is inescapable that our approaches, modalities of inquiry, and knowledge are influenced by the sentiments, experiences, possibilities, and anxieties of our time and location, not to talk of the global configurations of power that structure the ways of knowing and being. COVID-19 had dominated the news in the past seven months, especially since January 30 when the World Health Organization declared the novel coronavirus disease "a public health emergency of international concern (PHEIC)" - the technical term for a global pandemic. In May, I reached out to the editorial board members of the African Archaeological Review to explore the possibilities of a forum on the pandemic. All the responses were enthusiastic. I then took on the responsibility to define the scope of the forum and invited several colleagues in and outside of Africa to join the discussion. The invitation specifically asked potential contributors to respond in 2500 words or less to one or more of the following questions:

- How is the coronavirus pandemic affecting the way you conceptualize and think about the African past in terms of your interest in the study of social formations and social emergence?

\footnotetext{
A. Ogundiran $(\bowtie)$

Department of Africana Studies, The University of North Carolina at Charlotte, Charlotte, NC 28223, USA

e-mail: Ogundiran@uncc.edu
}

- How are you thinking or rethinking those instances of cultural change, cultural processes, biocultural evolution, social rootedness and mobility, perturbations, and resilience, as well as collapse and rejuvenation that you have observed in your areas of study, periods, and archaeological sites?

- How is this global pandemic affecting how you might approach, study, and interpret archaeological contexts and issues of heritage and human development?

- What relationships do you see between this pandemic and any of the past epidemical events in Africa?

- What insights can archaeology provide to inform the ways current pandemic is being managed on the continent?

- What can we learn in African archaeology and heritage studies from the social, political, economic, and ecological dimensions of the COVID-19 pandemic?

- What are the materialities of COVID-19 in different parts of Africa today, and what do they tell us about public anxieties, coping strategies, and sociopolitics of the pandemic?

The six essays featured in the following pages are the outcome of the project.

The first essay, by Ibrahima Thiaw, examines how the pernicious legacies of colonialism and racism loudly resonated in the initial apocalyptic projections by some Western observers on the likely impact of COVID-19 pandemic in Africa. The otherization of Africa and Africans as the antithesis of the West underlies some 
of these initial sentiments and anxieties. His reflections are poignant for understanding how this otherization has been the lynchpin of much of the theorizing and assumptions that frame how Africa is studied, taught, perceived, explained, and understood in the Western intellectual traditions, public discourses, and social policy agendas (also see Kea 2012, p. 12). It also affects the way many African elites see themselves and their society, leading to the kind of mimetic performances of coloniality that framed, for example, the Senegalese government's early responses to the pandemic. Thiaw also draws attention to a different type of performativity from below-the teranga aesthetic. He explains how this deeply rooted culture of communal sociability and solidarity has been deployed to cope with the uncertainties and anxieties of the pandemic. Finally, Thiaw explores the likely material imprints of the teranga aesthetic in the archaeological record. He is suggestive of how we may identify and "read" those material imprints to understand the ways many Senegalese mobilized their cultural heritage to manage pandemics and other stressors in the recent and deep past.

In her contribution, Kristina Douglass challenges archaeologists to practice the principle of resilience for which many African societies are known and which has driven the research inquiry of many archaeologists in the past two decades. Resilient practices, she argues, require archaeologists to invest upfront in community building as the foundation of their research endeavors. She uses her ongoing research in southwest Madagascar-The Morombe Archaeological Projectto illustrate the rich dividends that can accrue from investing in capacity building at the host community level. Her essay offers a blueprint on how to make foreign and local collaboration effective and resilient for coping with the disruptive moments like the one that COVID-19 has imposed on us.

The third essay shifts the gear to consider the possibilities and challenges of bioarchaeology of infectious diseases. Here, Susan Pfeiffer provides a succinct analysis of why it is difficult to identify plague and other epidemical events in archaeological contexts, especially in sub-Saharan Africa. It is not only that the "Infectious pathogens that kill their targets quickly do not leave telltale changes to the skeleton," according to Pfeiffer. The skeletons are also usually in poor preservation conditions in the humid environment and acidic soils that predominate in most parts of the continent. Moreover, she argues that pathogenic activities in the temperate zone are unlikely to manifest in the same way in the tropical environment. Lastly, she offers an exploratory insight on what we might learn from the nascent field of palaeogenomics about pathogens and human populations in Africa. Her essay evokes the need for systematic collaboration between palaeopathologists, bioarchaeologists, and other archaeology specialists in the quest to understand the roles of pathogens in Africa's deep past.

The end of the African humid period in the Sahara around ca. $5000 \mathrm{cal}$ year BP, and its likely impact on increased episodes of zoonotic diseases, is the focus of Augustin Holl's essay. The abrupt climate change created both challenges and opportunities for Africa's Neolithic pastoralists whose cultural innovations have been widely discussed as adaptive strategies for managing the unstable and harsh climate regimes of the Middle Holocene (e.g., Hildebrand et al. 2018; Holl 2013). The cattle and sheep/goat burials (whole and butchered animals) in monumental installations account for one of these cultural innovations. Holl, drawing from some of the recent studies in paleoenvironmental and archaeological research, observes that the burial of valuable domesticated animals, especially in the Messak plateau in southwest Libya, may have been related to efforts by the pastoralist populations to manage, preempt, curtail, and adjust to the increasing incidents of livestock zoonoses. His exploratory essay offers several pointers for understanding the relationships between climate change, the patterns of dry- and rainy-season transhumance, management of zoonoses, and rituals of community formation and renewal.

In the fifth essay, I emphasize the need to be attentive to the oral traditions, rituals, and other sources of memory of descendant communities when researching the archaeology of living cultures. The essay has two components. First, I show that the transformations that the Yorùbá region experienced during the tenth, late fourteenth, and early nineteenth centuries cannot be understood without paying attention to climatic and epidemic stressors. However, given the elasticity of human creativity and choices, the essay reiterates the caution against disease and climate determinisms for explaining the fate of social formations (e.g., McAnany and Yoffee 2009). The impacts of droughts and infectious diseases must be explored within the contexts of leadership, sociopolitics, economics, culture, and the ontologies that mediated those stressors. Densely populated towns and cities were the building blocks of ancestral Yorùbá 
sociopolitical organization, at least since the eleventh century. In the second component of the essay, I explore how sacred groves were likely used for managing the unpredictable epidemic outbreaks in those past urban landscapes.

Shadreck Chirikure provides closing remarks, "a sort of reflection on the reflections." His wide-ranging remarks explore what the COVID-19 moment means for African archaeology. He takes some of the salient issues in the five essays as points of both entry and departure. He ruminates on the encumbrances of coloniality in African archaeology and the persistent marginalization of African knowledge at the global levels. He also critiques the shortcomings in the current archaeology education in Africa. For archaeology to become an instrument of emancipatory and decolonial agendas in Africa, Chirikure is convinced that archaeology education must be retooled so that students are equipped with the skills and knowledge that can respond to African priorities. He also emphasizes the need for Africanist archaeologists to be attentive to local agencies and the kinds of collaborative frameworks that would make these local agencies accessible for conceptualizing and interpreting the past.

The following essays respond to and even transcend some of the questions posed above. They offer some possibilities for reimaging and reimagining the social practices of archaeology in Africa. The essays also provide directions for rethinking the conceptual and empirical frameworks of the archaeology of disease and epidemic. However, what we offer here is only a starter. Unfortunately, due to time constraints, some of our colleagues who showed interest were unable to complete their essay by the deadline. We welcome other forums that will explore additional perspectives on what it means to research, preserve, and disseminate knowledge in African archaeology during the "Age of COVID-19."

Acknowledgments My words of appreciation go the following editorial board members: Jonathan Aleru, Cameron Gokee, Chapurukha Kusimba, Adria LaViolette, Scott MacEachern, Sada Mire, and Ann Stahl, for their feedback at the conceptual stage of the forum. The contributors and I are also grateful to the anonymous reviewers and Foreman Bandama, Nicole Boivin, Gérard Chouin, Steven Goldberg, Elisabeth Hildebrand, Elgidius Ichumbaki, Shomarka Keita, and Jonathan Walz for providing insightful feedback at different stages of the project.

Note We dedicate this forum to all frontline and essential workers all over the world, especially in health, social, transportation, delivery, and educational services, and to the memory of those we have lost to the pandemic.

\section{References}

Hildebrand, E. A., Grillo, K. M., Sawchuk, E. A., Pfeiffer, S. K., Conyers, L. B....., \& Wang, H. (2018). A monumental cemetery built by eastern Africa's first herders near Lake Turkana, Kenya. Proceedings of the National Academy of Sciences of the United States of America, 115(36), 89428947.

Holl, A. F. C. (2013). Grass, water, salt, copper, and others: Pastoralists' territorial strategies in Central Sudan. Archaeological Papers of the American Anthropological Association, 22, 39-53.

Kea, R. A. (2012). A cultural and social history of Ghana from the seventeenth to the nineteenth century the Gold Coast in the age of trans-Atlantic slave trade (Vol. 1). Lewiston: Edwin Mellen Press.

McAnany, P., \& Yoffee, N. (Eds.). (2009). Questioning collapse: Human resilience, ecological vulnerability, and the aftermath of empire. Cambridge: Cambridge University Press.

Publisher's Note Springer Nature remains neutral with regard to jurisdictional claims in published maps and institutional affiliations. 